\title{
Effects of Dietary L-Glutamine or L-Glutamine Plus L-Glutamic Acid Supplementation Programs on the Performance and Breast Meat Yield Uniformity of \\ 42-d-Old Broilers
}

http://dx.doi.org/10.1590/1516-635xSpeciallssue Nutrition-PoultryFeedingAdditives093-098

\section{-Author(s)}

\author{
Ribeiro Jr VIII \\ Albino LFT' \\ Rostagno HS \\ Hannas MI' \\ Ribeiro CLN"II \\ Vieira RA"II \\ Araújo WAG delv \\ Pessoa GBS" \\ Messias RKG"II \\ Silva DL dall
}

Federal University of Viçosa, Department of Animal Science, Av PH Rolfs S/N, Viçosa 36570-000, MG, Brazil

" Ajinomoto do Brasil Ind. e Com. de Alimentos Ltda. Rua Vergueiro, $\mathrm{n}^{\circ} 1737$. Vila Mariana, São Paulo 04101-000, SP, Brazil

III Doctorate program-UFV/DZO

iv Federal Institute of Education, Science and Technology of Northern Minas Gerais, 39480-000, Brazil

\section{Mail Address}

Corresponding author e-mail address Valdir Ribeiro Junior

Rua São Geraldo, n²72, CEP. 36660-000 Além Paraíba, MG, Brazil.

E-mail: valdir.junior@ufv.br

\section{-Keywords}

Breast, growth, non-essential amino acids, uniformity.

\section{ABSTRACT}

This study aimed at evaluating four dietary L-Glutamine (L-Gln) or L-Gln plus L-Glutamate (L-Glu) supplementation programs on the performance, breast yield, and uniformity of broilers. A total of 2,112 one-d-old male Cobb $500^{\circledR}$ broilers were distributed according to a randomized block design in a $2 \times 4$ factorial arrangement (L-Gln or L-Gln plus L-Glu $\times 4$ supplementation programs), totaling eight treatments with 12 replicates of 22 broilers each. The supplementation programs consisted of the dietary inclusion or not of $0.4 \%$ of L-Gln or L-Gln plus L-Glu for four different periods: 0 days (negative control), 9d, 21d, and $42 \mathrm{~d}$. Feed intake ( $\mathrm{Fl}, \mathrm{g})$, body weight gain (BWG, g), feed conversion ratio $(F C R, \mathrm{~kg} / \mathrm{kg})$, coefficient of variation of body weight (CV, \%), body weight uniformity (UNIF, \%), breast weight (BW, g), breast yield (BY, $\%)$, coefficient of variation of breast weight $\left(\mathrm{CV}_{\mathrm{B}}\right)$, breast uniformity $\left(\mathrm{UNIF}_{\mathrm{B}}\right)$, coefficient of variation of breast yield $\left(\mathrm{CV}_{\mathrm{BY}}\right)$, and breast yield uniformity $\left(\mathrm{UNIF}_{\mathrm{BY}}\right)$ were evaluated. Birds fed the diets treatments supplemented with L-Gln or L-Gln plus L-Glu for 9 d presented $3 \%$ higher BWG $(p<0.05)$ compared with the controls. The L-Gln or L-Gln plus L-Glu supplementation until broilers were 21 days old resulted in $14,10,16$, and $12 \%$ improvements $(p<0.05)$ in $C V$, UNIF, $C_{B Y}, U_{N I F}$ respectively. The supplementation of $0.4 \% \mathrm{~L}-\mathrm{G} \ln (\mathrm{L}-\mathrm{G} \ln 99 \%)$ or L-Gln plus L-Glu (minimum 95\%) to pre-starter and starter broiler diets is recommended to improve body weight gain and uniformity.

\section{INTRODUCTION}

L-glutamine (L-GIn) is considered a non-essential amino acid (AA) because most animal cells are able to synthesize them (Murakami et al., 2007). It is the most prevalent AA in the bloodstream, accounting for around $35 \%$ of nitrogen $(\mathrm{N})$ in the plasma and in the free AA pool in the body (Newsholme et al., 1986). Additionally, the ability to receive and donate $\mathrm{N}$ makes of $\mathrm{L}-\mathrm{G}$ ln the main vehicle for nitrogen transfer between tissues (Bartell and Batal, 2007). L-Gln is the main metabolic fuel for small intestine enterocytes, lymphocytes, macrophages, and fibroblasts (Cynober, 1999; Andrews and Griffiths, 2002), and it is considered an essential amino acid in some species under inflammatory conditions, such as infection and injury (Newsholme, 2001). Also, it may stimulate feed intake through the production of orexigenic and anorexigenic neuropeptides in mammalian (Zeni et al., 2000) and chicken brain (Khondowe et al., 2012)

However, in certain pathological circumstances such as trauma and infection, specific tissues need a greater amount of L-Glutamine than muscle catabolism is capable of producing (Calder, 1994). Also, L-Glutamine may be converted to L-Glutamic acid (L-Glu) to produce immune response factors to be used against pathogen in the body (Newsholme et al., 2003). 
Ribeiro Jr V, Albino LFT, Rostagno HS, Hannas M, Ribeiro CLN, Vieira RA, Araújo WAG de, Pessoa GBS, Messias RKG, Silva DL da
Effects of Dietary L-Glutamine or L-Glutamine Plus L-Glutamic Acid Supplementation Programs on the Performance and Breast Meat Yield Uniformity of 42-d-Old Broilers
It is known that L-Glutamine influences intestinal development (Zaravize et al., 2011) and that the greatest growth rate of the gastrointestinal tract of broilers occurs during the first week of life (Uni \& Ferket, 2004). Also, it was reported that L-GIn supplementation may increase intestinal villus height in turkey poults (Yi et al., 2005) and that it may stimulate gut cell proliferation (Inoue et al., 1993, Sakamoto et al., 2011) that aid maintaining gut integrity, intestinal barrier function, and gut mucosal regeneration (Sanz et al., 2004), which is important for preventing bacterial infections. Adjei et al. (1994) reported that L-Gln has been shown to prevent intestinal hyperpermeability and bacterial translocation in mice submitted to immune challenge.

Moreover, there are few studies on L-GIn or L-Gln plus L-Glu supplementation in broiler diets according to rearing phase.

Currently, the nutritional broiler requirements are evaluated at different phases of life in order to formulate diets that meet their needs with greater precision (Rostagno et al., 2011).

Thus, the aim of this study was to evaluate the effect of dietary supplementation programs of L-Glutamine or L-Glutamine plus L-Glutamic acid on the performance, breast meat yield, and broiler uniformity.

\section{MATERIAL AND METHODS}

The study was carried out according to the recommendations of the Ethics Committee for Animal Use of the Department of Animal Science (DZO/ UFV), under protocol n. 38/2013.

The experiment was carried out at the Poultry Section of the Department of Animal Science, Federal University of Viçosa. The birds were distributed in a randomized block design using a $2 \times 4$ factorial arrangement (L-Gln or L-Gln plus L-Glu $\times 4$ periods, totaling eight treatments with 12 replicates of 22 birds per experimental unit. The experimental blocks were determined by positions interfering with ambient light.

In order to increase stress, birds were subjected to feed and water fasting for 24 hours upon their arrival at the experimental farm. Reused litter was used as challenge the broilers' health status.

Three basal diets were formulated (Table 1) to meet broiler nutritional requirements according to Rostagno et al.(2011), as a function of rearing phase.

The eight treatments consisted of inclusion of L-Gln or L-GIn plus L-Glu at $0.4 \%$ in the basal diets in different dietary supplementation programs: negative control (without supplemental L-Gln or L-Gln plus L-Glu in any of the experimental phases), and supplementation from d 1 to 9 , d 1 to 21 , or $d 1$ to 42 .

Table 1 - Ingredients and nutrient composition of the experimental diets ( $\mathrm{g} / \mathrm{kg}$ diet, on as-fed basis).

\begin{tabular}{|c|c|c|c|}
\hline Ingredients (g/kg) & $\begin{array}{l}\text { Pre-starter } \\
\text { (1 to } 9 d)\end{array}$ & $\begin{array}{c}\text { Starter } \\
(9 \text { to } 21 \mathrm{~d})\end{array}$ & $\begin{array}{l}\text { Grower/finisher } \\
\text { ( } 21 \text { to } 42 d)\end{array}$ \\
\hline Corn & 357.5 & 422.0 & 488.3 \\
\hline Soybean meal 45\% & 371.2 & 324.0 & 287.2 \\
\hline Sorghum & 150.0 & 150.0 & 150.0 \\
\hline Corngluten meal $60 \%$ & 50.0 & 40.0 & 0.0 \\
\hline Soybean oil & 21.8 & 19.5 & 37.8 \\
\hline Limestone & 9.2 & 9.1 & 7.6 \\
\hline Bi-calcium phosphate & 19.1 & 15.6 & 10.8 \\
\hline Salt & 5.1 & 4.8 & 4.5 \\
\hline L-lysine $\mathrm{HCl}, 79 \%$ & 2.8 & 2.5 & 2.0 \\
\hline DL-methionine, 99\% & 2.7 & 2.3 & 2.4 \\
\hline L-threonine, 98\% & 0.4 & 0.3 & 0.4 \\
\hline Choline chloride, $60 \%$ & 1.0 & 1.0 & 1.0 \\
\hline Mineral mixture ${ }^{1}$ & 1.3 & 1.1 & 0.8 \\
\hline Vitamin mixture $^{2}$ & 1.3 & 1.1 & 0.8 \\
\hline $\begin{array}{l}\text { Anticoccidial (salinomycin } \\
12 \% \text { ) }\end{array}$ & 0.5 & 0.5 & 0.5 \\
\hline Avilamycin & 0.1 & 0.1 & 0.1 \\
\hline $\mathrm{BHT}^{3}$ & 0.1 & 0.1 & 0.1 \\
\hline Starch ${ }^{4}$ & 6.0 & 6.0 & 6.0 \\
\hline \multicolumn{4}{|c|}{ Calculated values } \\
\hline Crude protein, g/kg & 244.3 & 221.4 & 185.1 \\
\hline Metabolizable energy, $\mathrm{kcal} / \mathrm{kg}$ & 2,950 & 3,000 & 3,150 \\
\hline Calcium, g/kg & 9.2 & 8.2 & 6.4 \\
\hline Available phosphorus, g/kg & 4.7 & 4.0 & 3.0 \\
\hline Digestible phosphorus, g/kg & 4.0 & 3.4 & 2.7 \\
\hline Sodium g/kg & 2.2 & 2.1 & 2.0 \\
\hline Potassium g/kg & 8.4 & 7.7 & 7.2 \\
\hline Digestible lysine, $\mathrm{g} / \mathrm{kg}$ & 13.1 & 11.7 & 10.1 \\
\hline Digestible Met+Cys, g/kg & 9.4 & 8.5 & 7.4 \\
\hline Digestible threonine, $\mathrm{g} / \mathrm{kg}$ & 8.5 & 7.6 & 6.6 \\
\hline
\end{tabular}

${ }^{1}$ Amount per kg of feed: Broilers: Pre-starter: Cu, 12.5 mg; Fe, 6.5 mg; I, 1,25 mg; Mn, $88 \mathrm{mg} ; \mathrm{Se}, 0.375 \mathrm{mg} ; \mathrm{Zn}, 81.3 \mathrm{mg}$. Starter: Cu, $11 \mathrm{mg} ; \mathrm{Fe}, 55 \mathrm{mg} ; \mathrm{l}, 1.10 \mathrm{mg} ; \mathrm{Mn}, 77$ mg; Se, 0.330 mg; Zn, $71.5 \mathrm{mg}$. Growerll (34 - 42 days): Cu, 7.5 mg; Fe, 37.5 mg; I, $0.75 \mathrm{mg} ; \mathrm{Mn}, 53 \mathrm{mg} ; \mathrm{Se}, 0.225 \mathrm{mg} ; \mathrm{Zn}, 48.8 \mathrm{mg}$.

${ }^{2}$ Amount per kg of feed: Pre-starter: Vit A, 9375 IU; Vit D 2375 IU, Vit E, 35 IU; Vit K ${ }_{3 \prime}$ $1.88 \mathrm{mg}$; Vit $B, 2.50$; Vit $B_{2}, 6.25 \mathrm{mg}$; Nicotinic acid, $37.5 \mathrm{mg}$; Pantothenic acid, 12.5 mg; Vit $B_{6}, 3.5$ mg; Vit $B_{12}, 0.015$ mg; Folic acid, 0.875 mg; Biotin, 0.088 mg; Starter: Vit $A, 8250$ IU; Vit D 2090 IU, Vit E, 31 IU; Vit K 13,65 mg; Vit B, 2.20; Vit $B_{2}, 5.5$ mg; Nicotinic acid, 33 mg; Pantothenic acid, 11 mg; Vit B $6^{\prime} 3.08$ mg; Vit B $B_{12} 0.013$ mg; Folic acid, $0.77 \mathrm{mg}$; Biotin, $0.077 \mathrm{mg}$; Choline, $330 \mathrm{mg}$. Grower II (34 - 42 days): Vit A, 5625 IU; Vit D, 1425 IU, Vit E, 21 IU; Vit K, 1.13 mg; Vit B 1, 1.50; Vit B, 3.75 mg; Nicotinic acid, $22.5 \mathrm{mg}$; Pantothenic acid, $7.5 \mathrm{mg}$; Vit $\mathrm{B}_{6^{\prime}} 2.10 \mathrm{mg}$; Vit $\mathrm{B}_{12^{\prime}} 0.009 \mathrm{mg}$; Folic acid, 0,525 mg; Biotin, $0.053 \mathrm{mg}$;

${ }^{3}$ Butyl hydroxy toluene

${ }^{4} \mathrm{~L}$-Glutamine and AminoGut ${ }^{\circledR}$ were added at the expense of starch in the experimental diets.

The evaluated products consisted of a commercial L-Glutamine (99\% of L-Glutamine) and AminoGut ${ }^{\circledR}$ as source of L-Glutamine plus L-Glutamic acid, which is a commercial dietary supplement containing a mixture of L-Glutamine and L-Glutamic acid (minimum 95\%). 
Ribeiro Jr V, Albino LFT, Rostagno HS, Hannas M, Ribeiro CLN, Vieira RA, Araújo WAG de, Pessoa GBS, Messias RKG, Silva DL da

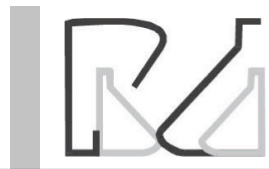

The following parameters were evaluated: feed intake $(\mathrm{Fl}, \mathrm{g})$; body weight gain (BWG, g); feed conversion ratio $(F C R, \mathrm{~kg} / \mathrm{kg})$; breast weight (BW, g); breast yield (BY, $\%)$; coefficients of variation of body weight $(\mathrm{CV}, \%)$, breast weight $\left(\mathrm{CV}_{\mathrm{B}^{\prime}} \%\right)$, and breast yield $\left(\mathrm{CV}_{\mathrm{BY}}, \%\right)$; and uniformity of body weight (UNIF, \%), breast weight $\left(\mathrm{UNIF}_{\mathrm{B}^{\prime}} \%\right)$, and breast yield $\left(\mathrm{UNIF}_{\mathrm{BY}}, \%\right)$.

On d42, 10 birds per pen were sacrificed to evaluate breast traits, according to Sakomura \& Rostagno (2007).

Data were analyzed using the MIXED procedure of SAS (SAS Institute, 2010). Data were submitted to analysis of variance (ANOVA) and means were compared using Tukey's test at 5\% probability level. In order to statistically analyze uniformity and coefficient of variation, all data were by applying the arcsine of the square root of the percentage value / 100. Then, this value was multiplied by $(180 / \pi)$ to obtain the data on degrees, and processed as shown by the following equation: UNIF or CV (degrees) $=[$ Arc sen $\sqrt{ } \% / 100 x$ $(180 / \pi)]$ (Carvalho, 2009).

The mixed model included the fixed effects of treatments, random effects of block, and residual
Effects of Dietary L-Glutamine or L-Glutamine Plus L-Glutamic Acid Supplementation Programs on the Performance and Breast Meat Yield Uniformity of 42-d-Old Broilers

error, as follows: The statistical model applied was: $Y_{i j k}$ $=\mu+\tau_{i}+\beta+(\tau \beta)_{i j}+\delta_{k}+\varepsilon_{i j, k^{\prime}}$ where $Y_{i j k}$ is the observation " $k$ " of $A A^{\prime \prime} i$ " in phase " $j " ; \mu$ is the overall mean; $\tau$ is the effect of $A A^{\prime \prime} i^{\prime} ; \beta$ is the effect of phase " $j " ;(\tau \beta)_{i, j}$ is the interaction of $A A^{\prime \prime} i$ " $\times$ phase " $j " ; \delta_{k}$ is the effect of block " $k$ "; and $\varepsilon_{i \mathrm{ijk}}$ is the residual random error.

\section{RESULTS AND DISCUSSION}

No interaction ( $p>0.05)$ was observed between L-GIn or L-GIn plus L-Glu supplementation and the dietary supplementation programs for any of the parameters evaluated during the experimental period. Similarly, there was no influence ( $p>0.05$ ) of the dietary supplementation of L-GIn or L-Gln plus L-Gluon any of the evaluated parameters (Table 2 ).

The treatments did not influence $\mathrm{Fl}, \mathrm{FCR}, \mathrm{BW}, \mathrm{BY}$, $\mathrm{CV}_{B^{\prime}}$ or $\mathrm{UNIF}_{\mathrm{B}}(\mathrm{p}>0.05)$. Some studies did not show any influence of dietary L-GIn or L-Glu supplementation on broiler $\mathrm{Fl}$ and FCR during different production phases (Bartell \& Batal, 2007; Fasina et al., 2010; Ayazi, 2014). Nevertheless, recent studies have been shown that glutamine and glutamate may induce the production

Table 2 - Experimental results obtained for broiler performance, breast characteristics, coefficient of variation and uniformity.

\begin{tabular}{|c|c|c|c|c|c|c|c|c|c|c|c|c|}
\hline \multirow{2}{*}{ Treatments } & & \multicolumn{11}{|c|}{ Parameters ${ }^{1}$} \\
\hline & & $\mathrm{FI}$ & BWG & FCR & CV & UNIF & BW & BY & $\mathrm{CV}_{\mathrm{B}}$ & $\mathrm{UNIF}_{\mathrm{B}}$ & $\mathrm{CV}_{\mathrm{BY}}$ & $\mathrm{UNIF}_{\mathrm{BY}}$ \\
\hline \multirow[t]{4}{*}{ L-Gln } & $\mathrm{Od}$ & 4159.8 & 2446.2 & 1.702 & 10.4 & 68.4 & 625.2 & 30.8 & 13.4 & 60.7 & 7.18 & 81.12 \\
\hline & $9 d$ & 4241.8 & 2541.3 & 1.669 & 10.0 & 70.7 & 634.6 & 31.2 & 12.6 & 56.5 & 6.43 & 83.47 \\
\hline & $21 d$ & 4219.5 & 2519.1 & 1.675 & 8.8 & 76.6 & 631.9 & 31.0 & 11.1 & 64.1 & 6.38 & 86.89 \\
\hline & $42 d$ & 4238.5 & 2555.9 & 1.659 & 8.5 & 78.9 & 647.6 & 31.5 & 11.0 & 64.6 & 5.58 & 94.63 \\
\hline \multirow[t]{4}{*}{ L-Gln+L-Glu } & $\mathrm{Od}$ & 4186.3 & 2472.1 & 1.695 & 10.0 & 69.1 & 625.5 & 31.1 & 12.7 & 59.8 & 7.41 & 80.55 \\
\hline & $9 d$ & 4185.8 & 2504.8 & 1.671 & 9.3 & 71.7 & 625.4 & 30.9 & 12.0 & 63.0 & 6.66 & 83.71 \\
\hline & $21 d$ & 4184.2 & 2503.0 & 1.672 & 8.5 & 76.9 & 630.1 & 31.2 & 11.7 & 61.0 & 6.15 & 85.92 \\
\hline & $42 d$ & 4211.5 & 2501.1 & 1.685 & 8.5 & 76.0 & 626.3 & 31.2 & 11.2 & 62.7 & 5.73 & 89.72 \\
\hline$p$-value & & 0.56 & 0.29 & 0.49 & 0.87 & 0.91 & 0.62 & 0.42 & 0.80 & 0.74 & 0.54 & 0.87 \\
\hline SEM & & 39.5 & 24.1 & 0.012 & 0.44 & 3.03 & 9.75 & 0.25 & 0.78 & 4.83 & 0.32 & 3.34 \\
\hline Od & & 4173.1 & $2459.1^{b}$ & 1.698 & $10.2^{b}$ & $68.8^{b}$ & 625.4 & 30.9 & 13.0 & 60.3 & $7.30^{\mathrm{b}}$ & $80.84^{b}$ \\
\hline $9 d$ & & 4213.8 & $2523.0^{\mathrm{a}}$ & 1.670 & $9.6^{b}$ & $71.2^{\mathrm{ab}}$ & 630.0 & 31.0 & 12.3 & 59.8 & $6.55^{\mathrm{ab}}$ & $83.59^{b}$ \\
\hline $21 d$ & & 4201.8 & $2511.1^{a}$ & 1.673 & $8.7^{\mathrm{a}}$ & $76.8^{a}$ & 631.0 & 31.1 & 11.4 & 62.6 & $6.26^{a}$ & $86.41^{\mathrm{ab}}$ \\
\hline $42 d$ & & 4225.0 & $2528.5^{a}$ & 1.672 & $8.5^{a}$ & $77.4^{\mathrm{a}}$ & 636.9 & 31.3 & 11.1 & 63.6 & $5.66^{a}$ & $92.17^{a}$ \\
\hline$p$-value & & 0.34 & $<0.01$ & 0.06 & $<0.01$ & 0.01 & 0.64 & 0.45 & 0.08 & 0.83 & $<0.01$ & 0.02 \\
\hline SEM & & 33.5 & 18.6 & 0.008 & 0.31 & 2.14 & 7.39 & 0.18 & 0.55 & 3.43 & 0.28 & 2.40 \\
\hline L-Gln & & 4214.9 & 2515.6 & 1.676 & 9.4 & 73.7 & 634.9 & 31.1 & 12.0 & 61.5 & 6.39 & 86.53 \\
\hline L-Gln+L-Glu & & 4191.9 & 2495.2 & 1.681 & 9.1 & 73.4 & 626.8 & 31.1 & 11.9 & 61.6 & 6.49 & 84.97 \\
\hline$p$-value & & 0.27 & 0.18 & 0.59 & 0.24 & 0.91 & 0.21 & 0.89 & 0.81 & 0.96 & 0.29 & 0.30 \\
\hline SEM & & 29.9 & 15.1 & 0.006 & 0.22 & 1.51 & 5.87 & 0.13 & 0.39 & 2.45 & 0.14 & 2.15 \\
\hline
\end{tabular}

a,b Means followed by different letters in the same column are significantly different by Tukey test at $5 \%$ probability level (p<0.05). SEM, pooled standard error of the means;

${ }^{1}$ Feed intake $(\mathrm{Fl}, \mathrm{g})$, body weight gain (BWG, g), feed conversion ratio (FCR, $\left.\mathrm{kg} / \mathrm{kg}\right)$, coefficient of variation of body weight(CV, \%), body weight uniformity (UNIF, \%), breast weight $(\mathrm{BW}, \mathrm{g})$, breast yield (BY, \%), coefficient of variation of breast weight $\left(\mathrm{CV}_{\mathrm{B}^{\prime}} \%\right)$, breast uniformity $\left(\mathrm{UNIF}_{\mathrm{B}^{\prime}} \%\right)$, coefficient of variation of breast yield $\left(\mathrm{CV}_{\mathrm{B}^{\prime}} \%\right)$, breast yield uniformity (UNIF $_{B Y,} \%$ ). 
Ribeiro Jr V, Albino LFT, Rostagno HS, Hannas M, Ribeiro CLN, Vieira RA,

Araújo WAG de, Pessoa GBS,

Messias RKG, Silva DL da
Effects of Dietary L-Glutamine or L-Glutamine Plus L-Glutamic Acid Supplementation Programs on the Performance and Breast Meat Yield Uniformity of 42-d-Old Broilers of orexigenic and anorexigenic neuropeptides, such as hypothalamic NPY, AgRP, POMC, MC4R, and CRF, in the brain, affecting mammalian (Zeni et al., 2000) and chicken (Khondowe et al., 2012) feed intake. Wang et al. (2012) also reported that administration of L-glutamate $(1.6 \mu \mathrm{mol})$ decreased feed intake and increased hypothalamic CRF and MC4R mRNA expression levels. However, in those studies, the AA were injected directly in the central nervous system (ICV), and therefore, further studies to evaluate the influence of glutamine and glutamate on broiler feed intake are needed.

The BWG, CV, UNIF, $\mathrm{CV}_{\mathrm{BY}}$ and $\mathrm{UNIF}_{\mathrm{BY}}$ were influenced $(p<0.05)$ by the evaluated treatments. The supplementation of L-GIn has been shown significant influence on broiler weight gain (Yi et al., 2005; Bartell \& Batal, 2007; Ayazi et al., 2014; Fathi et al., 2014; Shakeri et al., 2014). This suggests that glutamine supplementation may be indicated to reduce flock variation, which aids broiler carcass processing. These effects are possibly explained by the importance of glutamine as the most abundant free amino acid in the bloodstream, accounting for approximately 25$35 \%$ of the total free AA pool in the body and for over $60 \%$ of the total free AAs in the skeletal muscle (Zaravize et al., 2010). Glutamic acid also is recognized as substrate for the synthesis of non-essential amino acid, having crucial importance in modern low crude protein diets (Berres et al., 2010). In the first studies on glutamine, McKeehan (1982) gathered information showing the influence of glutaminolysis on perfect noncarcinogenic cell proliferation. Additionally, glutamine may improve intestinal mucosa development and gut health because it is used as energy substrate for highspeed replication tissues, such as the intestinal mucosa (enterocytes and colonocytes), presenting protective and restorative roles in humans (Sanz et al., 2004). Sifa et al. (2005) corroborated this influence on broiler gut. They reported evidences that glutamine dietary supplementation increases jejunum villus height and the thickness of the muscle layer of mucosa, and prevent the reduction of villus width and crypt depth. Other authors confirmed this concept, reporting that the jejunum was the first segment influenced by dietary Gln, followed by the ileum, while the duodenum was less affected (Yanfen et al., 2006). On the other hand, Murakami et al. (2006) observed greater development of the duodenum (segment with high enzyme activity), followed by the jejunum and the ileum. Additionally, the use of glutamine as substrate for gut cells may improve the production of some enzymes, such as maltase and sucrase, which improve nutrient hydrolysis and consequently absorption, and may enhance broiler growth rate (Sakamoto et al., 2011).

Birds fed diets with $0.4 \%$ L-Gln or L-Gln plus L-Glu until day 9 presented 3\% higher BWG $(p<0.05)$ compared with those fed the control diet. In addition, the dietary supplementation of L-GIn or L-Gln plus L-Glu from days 9-21 improved $(p<0.05) \mathrm{CV}$, UNIF, $\mathrm{CV}_{B Y}$, and $\mathrm{UNIF}_{\mathrm{BY}}$ in $14,10,16$, and $12 \%$, respectively. This phase is critical for the development of the small intestine and for the stimulation of the production of mucosal enzymes, on which dietary L-GIn has considerable proven effects (Sifa et al., 2005, Yanfen et al., 2006; and Sakamoto et al., 2011). The nutrition of broilers during the first week after hatch has been extensively studied due to the strong correlation between body weight on day 7 and body weight at slaughter. Moreover, this phase represents about 20\% of the life of a broiler, when the fastest growth rate of the gut occurs (Uni and Ferket, 2004).

These results suggest that the supplementing broiler diets with L-Gln or L-GIn plus L-Glu during the first 21 days of live is sufficient to obtain benefits during the entire production period. These effects may be explained by the importance of the gastrointestinal development of broilers during the starter rearing phase. Manvailer (2013) observed that the best L-GIn supplementation strategy was $1.0 \%$ of L-Glutamine until 14 days of age, $0.5 \%$ of L-Glutamine until 21 days, and $0.0 \%$ between 22 to 42 days of age, resulting in greater body weight, body weight gain, carcass weight, breast weight, and breast yield. Similarly, Zavarize et al. (2011) observed that the inclusion of $1.0 \% \mathrm{~L}-\mathrm{Gln}$ in the diet of broilers from 1 to 21 days reared under non-stressful conditions improved broiler performance, and suggested that AA supplementation during the finisher phase was not necessary. However, the different criteria used for this evaluation among studies may yield different results. Sakamoto et al. (2011) observed a linear increase in maltase activity in 14-d-ol broilers and in sucrase activity in 42-d-old broilers fed increasing levels of L-GIn plus L-Glu (AminoGut ${ }^{\circledR}$ ). Those authors concluded that dietary supplementation of these AA is important in broiler nutrition, and recommend the use $2.8 \%$ of L-GIn plus L-Glu until 42 days of age. Therefore, it seems that beneficial results are achieved with L-GIn or L-GIn plus L-Glu supplementation during the entire production cycle of broilers. However, the impact of this supplementation is more evident during the starter phase, probably due to the development of the gut in these animals (Maiorka et al., 2002; Sakamoto et al., 2006; Murakami et al., 2007). 
Ribeiro Jr V, Albino LFT, Rostagno HS, Hannas M, Ribeiro CLN, Vieira RA, Araújo WAG de, Pessoa GBS, Messias RKG, Silva DL da

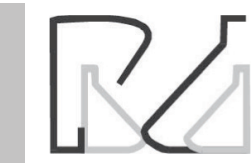

Effects of Dietary L-Glutamine or L-Glutamine Plus L-Glutamic Acid Supplementation Programs on the Performance and Breast Meat Yield Uniformity of 42-d-Old Broilers
One of the main consequences of the lack of body uniformity in commercial broiler production systems is the incidence of clinical and subclinical diseases (Russel, 2003). Therefore, considering that L-GIn and L-GIn may promote intestinal mucosa health, some diseases may be prevente. Yi et al. (2005) reported that diets containing $1 \% \mathrm{~L}-\mathrm{Gln}$ fed during the first 48 hours of the broilers' life improved growth, stimulated IFN- $\gamma$ (ng/ $\mathrm{mL}$ ) production, and decreased the mortality of animals contaminated with E. maxima at 7 and 14 days of age. Also, lymphoid organs can be improved by L-GIn dietary supplementation. Huang et al. (2007) observed higher BWG and growth enhancement of the immune organs (thoracic gland, spleen and bursa of Fabricius) of broilers fed glutamine. In addition of enhancing the immune response, dietary L-GIn supplementation may aid the body to fight against microbes that invade the body by enhancing the protection against secondary adverse effects on the immune system, such as peroxide production. Jing Ge et al. (2009) showed a significant increase in superoxide dismutase and GSH-Px levels, improving the antioxidant capacity of broilers fed diets with $0.5 \% \mathrm{~L}-\mathrm{Gln}$. Testing high stocking densities under tropical conditions, Shakeri et al. (2014) verified reduced mortality rates in broilers fed diets with L-GIn plus L-Glu.

Among the possible explanations for these results are the better intestinal integrity, enhanced immune response, and better antioxidant protection provided by glutamine and glutamate, ultimately leading to overall better health status of the birds. Therefore, the results of the present study corroborate several previous research studies of the role of those AA in broiler nutrition and suggests that glutamine or glutamine combined with acid glutamic can be supplemented in pre-starter and starter diet to improve broiler performance and reduce body weight variation in broiler flocks.

\section{CONCLUSION}

The dietary supplementation of pre-starter and starter diets with $0.4 \% \mathrm{~L}-\mathrm{G} \ln (\mathrm{L}-\mathrm{G} \ln 99 \%)$ or L-Gln plus L-Glu (minimum 95\%) is recommended to improve the performance, breast weight, and uniformity of broilers.

\section{ACKNOWLEDGEMENTS}

We thank to the Universidade Federal de Viçosa - UFV, the Conselho Nacional de Desenvolvimento Cientifico e Tecnológico (CNPq, Brazil), and the Ajinomoto do Brasil Ind. e Com. de Alimentos Ltda -Ajinomoto Animal Nutrition.

\section{REFERENCES}

Adjei AA, Matsumoto Y, Tsuneyuki O, Hiroi Y, Yamamoto S. Dietary arginine and glutamine combination improves survival in septic mice. Nutrition Research 1994; 14 (10): 1591-1599.

Andrews FJ, Griffiths RD. Glutamine: Essential for immune nutrition in the critically ill. British Journal of Nutrition 2002; 51: 3-8.

Ayazi M. The effect of dietary glutamine supplementation on performance and blood antioxidant status of broiler chickens under continuous heat stress condition. International Journal of Farming and Allied Sciences 2014; 3(12): 1213-1219.

Bartell SM, Batal AB. The effect of supplemental glutamine on growth performance, development of the gastrointestinal tract, and humoral immune response of broilers. Poultry Science 2007; 86:1940-1947.

Berres J, Vieira SL, Dozier WA. Broiler responses to reduced-protein diets supplemented with valine, isoleucine, glycine, and glutamic acid. The Journal of Applied Poultry Research 2010; 19:68-79.

Calder PC. L-Glutamine and the immune system. Clinical Nutrition 1994; $13,2-8$

Carvalho TA. Avaliação de dietas com glutamina e glicina para pintos de corte contendo diferentes relações treonona: lisina. [Dissertation]. Viçosa (MG): Universidade Federal de Viçosa; 2009

Cynober LA. Glutamine metabolism in stressed patients. In: International Congress on Amino Acids, Germany; 1999. Proceedings... (Germany).

Fasina YO, Bowers JB, Hess JB, Mckee SR. Effect of dietary glutamine supplementation on salmonella colonization in the ceca of young broiler chicks. Poultry Science 2010; 89: 1042-1048.

Fathi M, Tanha T, Daneshyar M. Effects of glutamine supplementation on growth performance and antioxidant status in broilers with pulmonary hypertension syndrome (PHS). Iranian Journal of Applied Animal Science 2014; 4(3): 579-585

Huang XL, Huang GQ, Huang YJ. Effect of glutamine and glycyl-glutamine on daily gain and developing performance of immunity organs of yellow-feathered broilers. China Animal Husbandry and Veterinary Medicine 2007; 34(6): 9-11

Inoue Y, Grant JP, Snyder PJ. Effect of glutamine-supplemented tota parenteral nutrition on recovery of the small intestine after starvation atrophy. Journal of Parental and Enteral Nutrition 1993; 17(2): 165170

JingGe D, XiaoTing Z, JiaCheng $H$, YunFang Q, Ke S. Effects of dietary supplementation of glutamine on meat quality and antioxidant indexes of broilers. Chinese Journal of Animal Nutrition 2009; 21(2): 245-250.

Khondowe P, Wang S, Chen S, Yu J, Zhu X, Wang L, Gao P, Xi Q, Zhang $Y$, Shu $G$, Jiang $Q$. Effects of central administration of glutamine and alanine on feed intake and hypothalamic expression of orexigenic and anorexigenic neuropetides in broiler chicks. Journal of Integrative Agriculture 2012; 11(7): 1173-1180.

Maiorka A, Boleli IC, Macari M. Desenvolvimento e reparo da mucosa intestinal. In: Macari M, Furlan RL, Gonzales E, editores. Fisiologia aviária aplicada a frangos de corte. Jaboticabal: Funep-Unesp; 2002. p. 113-123

Manvailer, G.V. L-Glutamina para frangos de corte criados em ambiente quente. [Dissertation]. Campo Grande (MS): Universidade Federal do Mato Grosso do Sul; 2013

McKeehan W. Glycolysis, glutaminolysis and cell proliferation. Cell Biology International Reports 1982; 6(7): 635-650. 
Ribeiro Jr V, Albino LFT, Rostagno HS,

Hannas M, Ribeiro CLN, Vieira RA,

Araújo WAG de, Pessoa GBS,

Messias RKG, Silva DL da

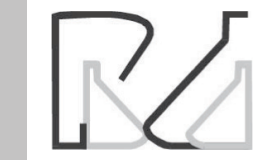

Effects of Dietary L-Glutamine or L-Glutamine Plus L-Glutamic Acid Supplementation Programs on the Performance and Breast Meat Yield Uniformity of 42-d-Old Broilers
Murakami AE, Sakamoto MI, Natali MRM, Souza LMG, Franco JRG, 2007. Supplementation of L-glutamine and vitamin e on the morphometry of the intestinal mucosa in broiler chickens. Poultry Science 2007; 86: 488-495

Newsholme P, Curi R, Gordon S, Newsholme EA. Metabolism of glucose, glutamine, long-chain fatty acids and ketone bodies by murine macrophages. Biochemical Journal 1986; 239: 121-125.

Newsholme P, Lima MM, Procopio J, Pithon-curi TC, Doi SQ, Bazotte RB, Curi R. L-glutamine and L-glutamate as vital metabolites. Brazilian Journal of Medical and Biological Research 2003; 36: 153-163.

Newsholme P. Why is L-glutamine metabolism important to cells of the immune system in health, post injury, surgery or infection? Journal of Nutrition 2001; 131: 2515S-2522S.

Rostagno HS, Albino LFT, Donzele JL. Tabelas brasileiras para aves e suínos: composição de alimentos e exigências nutricionais. UFV, Viçosa, 3st edition, $2011251 \mathrm{p}$

Russel SM. The effect of airsacculitis on bird weights, uniformity, fecal contamination, processing errors, and populations of Campylobacter spp. and Escherichia coli. Poultry Science 2003; 82(8): 1326-1331.

Sakamoto MI, Faria DE, Nakagi VS, Negrão JA, Araújo RB, Souza KMR, Previero TC. Utilization of glutamine, associated with glutamic acid, on development and enzymatic activity in broiler chickens. Arquivo Brasileiro de Medicina Veterinária e Zootecnia 2011; 63 (4): 962-972.

Sakamoto MI, Murakami AE, Silveira TGV, Fernandes JIM, Oliveira CAL. Influence of L-glutamine and vitamin e on the performance and the immune responses of broiler chickens. Brazilian Journal of Poultry Science 2006; 8: 243-249

Sakomura NK, Rostagno HS. Métodos de pesquisa em nutrição de monogástricos. Funep, Jaboticabal, 3st edition, 2007 283p.

Sanz A, Celaya S, Gracia P, Gracia ML, Albero YR. Inmunonutrición. Endocrinología y Nutrición 2004; 51(4): 202-217.

SAS Institute, Inc., 2010. SAS OnlineDoc® Version 9.1.3, Cary, NC, USA.
Shakeri M, Zulkifli I, Soleimani AF, O'Reilly EL, Eckersall PD, Anna AA, Kumari S, Abdullah FFJ. Response to dietary supplementation of L-glutamine and L-glutamate in broiler chickens reared at different stocking densities under hot, humid tropical conditions. Poultry Science 2014; 93: 2700-2708

Sifa D, Youzhi L, Rulan L, Dongliang $H$. Influence of glutamine supplementation on jejunum morphological structure in Broiler chickens. Chinese Journal of Animal and Veterinary Sciences 2005; 36(1): 100-104.

Uni Z, Ferket RP. Methods for early nutrition and their potential. Poultry Science 2004; 60: 101-111.

Wang S, Khondowe P, Chen S. Effects of "Bioactive" amino acids leucine, glutamate, arginine and tryptophan on feed intake and mRNA expression of relative neuropeptides in broiler chicks. Journal of Animal Science and Biotechnology 2012; 3 (27): 1-8.

Yanfen $\mathrm{L}$, Jiansheng $\mathrm{M}$, Xiaoliang $\mathrm{H}$. Effect of glutamine supplementation on development of small intestine, structure and absorption of broilers. Chinese Agricultural Science Bulletin 2006; 22(8):39-39.

Yi GF, Allee GL, Knight CD, Dibnert JJ. Impact of L-glutamine and oasis hatchling supplement on growth performance, small intestinal morphology, and immune response of broilers vaccinated and challenged with Eimeria maxima. Poultry Science 2005; 84: 283-293.

Zaravize KC, Sartori JR, Pelícia VC, Pezzato AC, Araujo PC, Stradiotti AC, Madeira LA. L-glutamine and nucleotide supplementation in broiler diets in alternative breeding system. Archivos de Zootecnia 2011; 60(232): 913-920

Zavarize KC, Menten JFM, Traldi AB, Santarosa J, da Silva CLS. Utilização de glutamina na nutrição de monogástricos. Revista Portuguesa de Ciências Veterinárias 2010; 105(573-576): 5-10.

Zeni LA, Seidler HB, de Carvalho NA, Freitas CG, Marino-Neto J, Paschoalini MA. Glutamatergic control of food intake in pigeons: effects of central injections of glutamate, NMDA, and AMPA receptor agonists and antagonists. Pharmacology, Biochemistry and Behavior 2000; 65(1): $67-74$ 